\title{
Role of cytokines in thymus- versus peripherally derived-regulatory $\top$ cell differentiation and function
}

\author{
Jérémie David Goldstein ${ }^{1,2,3 t \neq}$, Louis Pérol ${ }^{4,5,6 \neq}$, Bruno Zaragoza ${ }^{1,2,3}$, Audrey Baeyens ${ }^{1,2,3}$, Gilles Marodon ${ }^{1,2,3 \neq}$ \\ and Eliane Piaggio ${ }^{4,5,6 * \neq}$
}

1 Université Pierre et Marie Curie Univ Paris 06, INSERM U959, Paris, France

${ }^{2}$ Centre National de la Recherche Scientifique, UMR 7211, Paris, France

${ }^{3}$ Institut National de la Santé et de la Recherche Médicale (INSERM), U959, Immunology-Immunopathology-Immunotherapy (I3), Paris, France

${ }^{4}$ INSERM U932, Paris, France

${ }^{5}$ Section Recherche, Institut Curie, Paris, France

${ }^{6}$ INSERM Center of Clinical Investigation (CBT507 IGR-Curie), Paris, France

Edited by:

Eyad Elkord, United Arab Emirates University, UAE; University of Salford and University of Manchester, UK

\section{Reviewed by:}

Sylvie Lesage, University of Montreal, Canada

Daniel Gray, The Walter and Eliza Hall Institute for Medical Research,

Australia

Johan Verhagen, University of Bristol, UK

\section{*Correspondence:}

Eliane Piaggio, INSERM U932,

Institut Curie, 26 rue d'Ulm, 75005

Paris, France

e-mail: eliane.piaggio@yahoo.com

\section{${ }^{\dagger}$ Present address:}

Jérémie David Goldstein, Department of Cellular Immunology, Institute of

Research in Biomedicine, Bellinzona, Switzerland.

₹ Jérémie David Goldstein, Louis Pérol, Gilles Marodon and Eliane Piaggio have contributed equally to this work.
$\mathrm{CD} 4^{+}{ }^{\mathrm{CD}} 25^{+} \mathrm{Foxp}^{+}$regulatoryT cells (Tregs) are essential players in the control of immune responses. Recently, accordingly to their origin, two main subsets of Tregs have been described: thymus-derived Tregs (tTregs) and peripherally derived Tregs (pTregs). Numerous signaling pathways including the IL-2/STAT5 or the TGF- $\beta / S m a d 3$ pathways play a crucial role in segregating the two lineages. Here, we review some of the information existing on the distinct requirements of IL-2, TGF- $\beta$, and TNF- $\alpha$ three major cytokines involved in tTreg and pTreg generation, homeostasis and function. Today it is clear that signaling via the IL$2 \mathrm{R} \beta$ chain (CD122) common to IL-2 and IL-15 is required for proper differentiation of tTregs and for tTreg and pTreg survival in the periphery. This notion has led to the development of promising therapeutic strategies based on low-dose IL-2 administration to boost the patients' own Treg compartment and dampen autoimmunity and inflammation. Also, solid evidence points to TGF- $\beta$ as the master regulator of $p$ Treg differentiation and homeostasis. However, therapeutic administration of TGF- $\beta$ is difficult to implement due to toxicity and safety issues. Knowledge on the role of TNF- $\alpha$ on the biology of Tregs is fragmentary and inconsistent between mice and humans. Moreover, emerging results from the clinical use of TNF- $\alpha$ inhibitors indicate that part of their anti-inflammatory effect may be dependent on their action on Tregs. Given the profusion of clinical trials testing cytokine administration or blocking to modulate inflammatory diseases, a better knowledge of the effects of cytokines on tTregs and pTregs biology is necessary to improve the efficiency of these immunotherapies.

Keywords: tTreg, pTreg, IL-2, TNF- $\alpha$, TGF- $\beta$, regulatory T cells, Foxp3
Thymus-derived Tregs (tTregs), which emerge from the thymus as a distinct lineage, and peripherally derived Tregs (pTregs), which are generated outside the thymus from $\mathrm{CD} 4{ }^{+} \mathrm{CD} 25^{-} \mathrm{T}$ cell precursors under particular conditions of stimulation, present great similarities, and differences. They are both defined by the expression of the transcription factor Foxp3, widely recognized as the master regulator of Treg fate. This factor, expressed quite specifically by Tregs (Fontenot et al., 2003; Hori et al., 2003) is required for their suppressive function both in vitro and in vivo (Fontenot et al., 2003, 2005a; Hori et al., 2003). But Tregs' specific genetic signature is only partially dependent on Foxp3 (Sugimoto et al., 2006; Gavin et al., 2007; Hill et al., 2007; Lin et al., 2007; Ohkura et al., 2012). And, in order to acquire this exclusive signature and mature into a stable lineage, both tTregs and pTregs will go through a process of "education" in several steps and different localizations. Here, we will describe the role of cytokines during this process. The role of the TCR in Treg development and of cytokines in Treg effector mechanisms have been the subject of recent excellent reviews (Vignali et al., 2008; Ohkura et al., 2013) and will not be extensively discussed here.

\section{THYMIC DERIVED Treg CELLS}

tTregs have been defined by the constitutive expression of the high affinity IL-2R $\alpha$ chain, CD25 (Sakaguchi et al., 1995). They are selected in the thymus based on their recognition of self-antigens by a TCR of high avidity (Jordan et al., 2001) and represent an important fraction of the total Tregs found in periphery (Hsieh et al., 2006; Josefowicz et al., 2012a). Removal of the thymus early after birth leads to various autoimmune symptoms (Itoh et al., 1999), suggesting that tTregs participate in the continuous prevention of spontaneous autoimmunity.

\section{IL-2 REGULATES BOTH THYMIC DEVELOPMENT AND PERIPHERAL HOMEOSTASIS OF tTreg}

The role of IL-2 in tTreg differentiation and homeostasis has been extensively studied. Early work showed that mice deficient for 
IL-2 or CD25 were profoundly deprived of Tregs in the periphery but not in the thymus (D'Cruz and Klein, 2005; Fontenot et al., 2005b), suggesting that IL-2 was mandatory for Treg homeostasis in the periphery but not for thymic generation. However, mice doubly deficient for IL- 2 and IL-15, or for the IL-2R $\beta$ chain (CD122) common to IL-2 and IL-15, present a quasi-complete depletion of thymic Treg cells (Burchill et al., 2007; Soper et al., 2007). Consequently, the CD122 signaling is mandatory for proper differentiation of tTregs. At the molecular level, binding of the CD122 signaling intermediate STAT5 to the conserved non-coding DNA sequence 2 (CNS2) element at the Foxp3 locus is required for optimal Foxp3 expression (Zorn et al., 2006; Burchill et al., 2007; Yao et al., 2007; Mouly et al., 2010) (for a recent review on the role of cytokine-induced transcription factors regulating Foxp3 expression, see Merkenschlager and von Boehmer, 2010). Demethylation of the CNS2 is the hallmark of stable Tregs but the role played by IL-2 in this process appears minimal since IL-2 cannot drive demethylation of the CNS2 in CD25 ${ }^{\text {hi }}$ Foxp $3^{-}$tTreg precursor if applied in the absence of TCR signals (Toker et al., 2013). Indeed, this precursor population expresses Foxp3 in vitro upon IL-2 stimulation without requirement for additional TCR signaling (Lio and Hsieh, 2008). Thus, a two-step model for Treg differentiation has been proposed in which TCR/CD28 signals first induce the differentiation of this precursor with enhanced sensitivity to IL-2/IL-15, followed by direct Foxp3 induction by IL-2/IL-15 signaling in a STAT5-dependent TCR-independent manner (Burchill et al., 2008; Lio and Hsieh, 2008). However, we believe that this two-step model is incomplete. Indeed, we have recently demonstrated that a minority of tTreg precursors expressed PSTAT5 ex vivo in unmanipulated neonates and we propose that this subset might be the direct precursors of pSTAT5 $^{+}$ $\mathrm{CD}^{2} 5^{+}$Foxp $3^{+}$tTregs (Figure 1) (Goldstein et al., 2011). Nevertheless, not all Foxp $3^{+} \mathrm{T}$ cells express pSTAT5, suggesting either that Foxp3 expression can be maintained without continuous
STAT5 phosphorylation or that differentiation of tTreg may proceed through a STAT5-independent pathway. Thus, the exact mechanism by which CD122 signaling controls the generation of tTregs remains to be determined.

Outside the thymus, the role of IL- 2 on Treg homeostasis is widely accepted: no IL-2, no functional tTregs in the periphery. Results obtained in mice deficient for IL-2 (Sadlack et al., 1993, 1995) or its receptor (Suzuki et al., 1995; Willerford et al., 1995), which develop extensive lymphadenopathy and die of systemic auto-immunity early after birth, extended the role of IL-2 from a "T Cell Growth Factor" (Smith et al., 1980) to "the gatekeeper of immunological tolerance". The autoimmunity observed in IL-2/IL-2R KO mice (whether CD25, CD122, or CD132 KO, the different components of the IL-2R) is associated with a profound deficit in Treg numbers and function, suggesting that tTregs generated in the absence of IL-2/IL-2R signaling cannot survive in the periphery. This view has been challenged by others, who reported the presence of Foxp $3^{+}$cells in the periphery of IL-2 KO mice (Liston et al., 2007). Noteworthy is the lack of autoimmunity in this later study. Thus, the association between the lack of IL2 , Treg deficit, and autoimmune manifestations cannot be always made. In further support of an important role for IL-2 in Treg survival, in vivo neutralization of IL-2 by the injection of an anti-IL-2 antibody results in the rapid depletion of Tregs and in the appearance of systemic, albeit limited, autoimmunity (Setoguchi et al., 2005). IL-2 is required for the maintenance of Foxp3 protein and mRNA expression both in vitro and in vivo (Setoguchi et al., 2005; Murawski et al., 2006; Passerini et al., 2008; Rubtsov et al., 2010). Furthermore, Tregs are crucially dependent on paracrine IL-2 production by effector T cells (Teffs), as they cannot produce IL-2 due to direct Foxp3-mediated repression of IL-2 transcription (Wu et al., 2006). Worth mentioning, the number of Tregs is indexed to the number of IL-2 producing Teffs (Almeida et al., 2006). In addition, polymorphisms in IL-2, CD25, or downstream adaptors

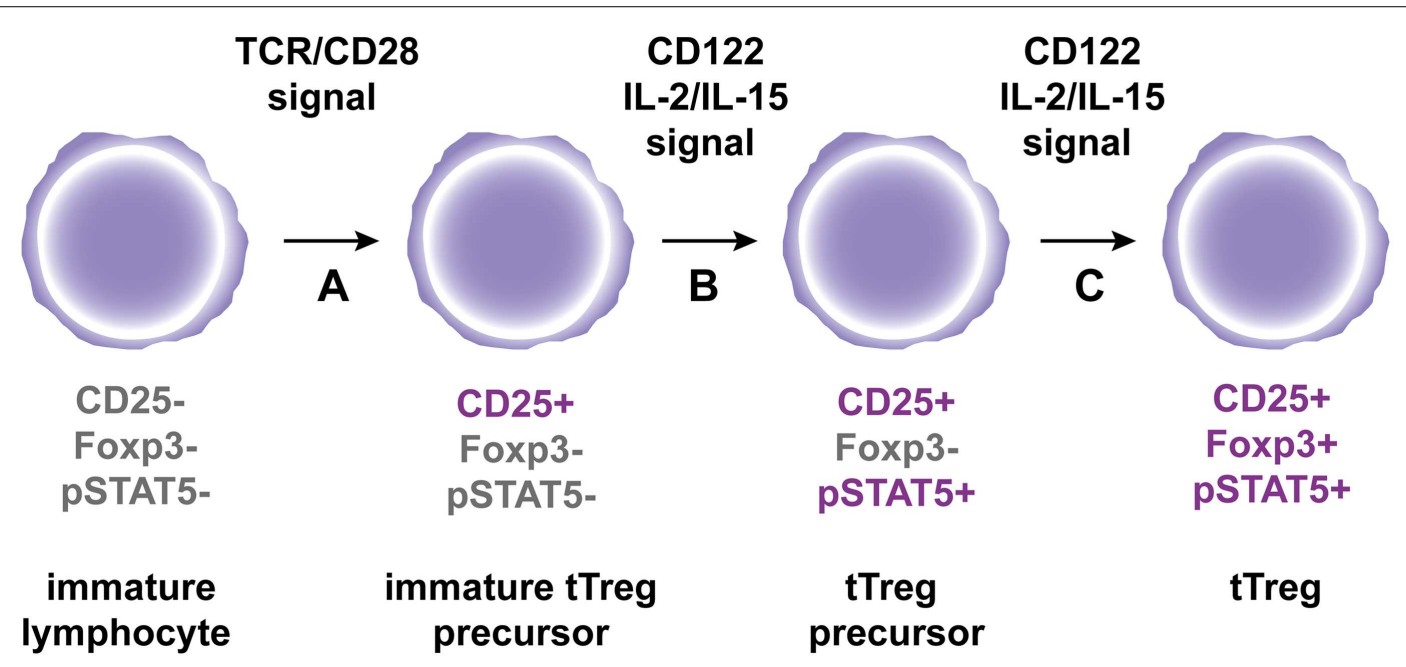

FIGURE 1 | A hypothetic model for tTreg differentiation in the thymus. (A) Immature $\mathrm{CD}^{+}$thymocytes are engaged by strong agonist $\mathrm{TCR} / \mathrm{co}$-stimulatory signals, which results in the expression of the IL2R alpha chain CD25. (B) Subsequent interaction of immature tTreg precursors with

CD122 signaling cytokines IL-2 and IL-15 leads to STAT5 phosphorylation to generate tTreg precursors. (C) Following continuous engagement of CD122, Foxp3 expression is induced in tTreg precursors to generate fully mature tTregs. 
genes are associated with impaired Treg numbers or function and higher susceptibility to autoimmunity (Bottini et al., 2004; Vella et al., 2005; Todd et al., 2007; Yamanouchi et al., 2007; Liston et al., 2008; Sgouroudis et al., 2008, 2011). Indeed, we and others have shown that IL-2 administration to mice (Tang et al., 2008; Wilson et al., 2008; Webster et al., 2009; Grinberg-Bleyer et al., 2010a; Dinh et al., 2012) and humans (Koreth et al., 2011; Saadoun et al., 2011) increases Treg numbers, reinforces their suppressive function, and protects from chronic inflammation. Indeed, low-dose IL-2 administration to pre-diabetic NOD mice which prevents disease development, increases Treg proportions specifically in the pancreas and these IL-2 expanded Tregs express higher levels of Bcl-2, CD25, and Foxp3, suggestive of increased resistance to apoptosis and higher activation (Tang et al., 2008). Furthermore, IL-2 administration to new onset diabetic NOD mice which reverts hyperglycemia, does not significantly increase Treg frequencies, yet Tregs express higher levels of molecules associated to Treg function, such as CD25, Foxp3, GITR, and ICOS and there is a decreased production of IFN- $\gamma$ by pancreas infiltrating $\mathrm{CD}^{+} \mathrm{T}$ cells (Grinberg-Bleyer et al., 2010a). These results suggest that IL2-boosted Tregs may have an improved suppressive function. The demonstration that IL-2 is critical for Treg biology has opened new perspectives for the treatment of inflammatory diseases.

\section{A MORE UNCERTAIN ROLE FOR TGF- $\beta$ ON tTreg DEVELOPMENT AND FUNCTION}

The role of TGF- $\beta$ during tTreg differentiation is controversial. Mice deficient for TGF- $\beta$ (Shull et al., 1992; Marie et al., 2005) or for either one subunit of its receptor (Gorelik and Flavell, 2000; Leveen et al., 2002; Li et al., 2006; Marie et al., 2006; Liu et al., 2008) develop a lethal autoimmune syndrome associated with a deficit in Tregs (Fahlen et al., 2005; Marie et al., 2005, 2006; Almeida et al., 2006; Li et al., 2006; Liu et al., 2008). Interestingly, this syndrome is only seen if TGF- $\beta$ is silenced early in T cell differentiation, suggesting that besides a deficit in tTreg, lymphopenia is an additional trigger of autoimmunity in the absence of TGF- $\beta$ signaling (Zhang and Bevan, 2012). At the molecular level, TGF- $\beta$ triggers the binding of Smad3/NFAT complex on the promoter and on the CNS1 enhancer regions of the Foxp3 gene (Tone et al., 2008). However, mice deficient for CNS1 have no alteration in tTreg differentiation (Zheng et al., 2010), suggesting that TGF- $\beta$ is not required for this process. But mice deficient for both TGF- $\beta$ and IL-2 are completely deprived of tTregs (Liu et al., 2008), suggesting that TGF- $\beta$ might compensate a defect in IL-2 and induce Foxp3 expression. How and when IL- 2 and TGF- $\beta$ signaling pathways intersect in the thymus to generate Foxp $3^{+}$cells remains to be fully elucidated.

Very few studies have focused on the potential role of TGF- $\beta$ on tTreg homeostasis and function. In the previously cited study from the group of Alexander Rudensky (Marie et al., 2005), the TGF- $\beta 1$ deficient mice that presented reduced frequencies of $\mathrm{CD} 4{ }^{+} \mathrm{CD} 25^{+}$ cells, also showed reduced Foxp3 expression among these cells. In addition, Treg deficient for the TGF- $\beta$ RII showed decreased suppressive function in vitro. However, this early study used total $\mathrm{CD} 4{ }^{+} \mathrm{CD} 25^{+}$peripheral cells as Tregs, which contains both tTregs and pTregs. Thus, it was impossible at the time to exclude that the effect came from a specific impact of TGF- $\beta$ on the pTreg subset. More recently, the same group clarified the situation. Indeed, they showed that tTregs purified from CNS1-deficient mice, which present altered TGF- $\beta$ signaling and lack pTreg differentiation (Zheng et al., 2010; Josefowicz et al., 2012a), did not present altered suppressive function or decreased Foxp3 expression (Josefowicz et al., 2012a). Taken together, these studies suggested that TGF- $\beta$ is not a main player in tTreg homeostasis or maintenance of Foxp3 expression and suppressive function in these cells.

\section{TNF- $\alpha$ SEEMS TO PARTICIPATE TO tTreg DEVELOPMENT AND HAS A CONTROVERSIAL ROLE ON TTreg FUNCTION}

TNF- $\alpha$, a pleiotropic cytokine well known for its major role in the initiation and orchestration of the pro-inflammatory immune response, may also display anti-inflammatory effects (Jacob and McDevitt, 1988; Yang et al., 1994). Mechanistically, TNF- $\alpha$ signals through two different receptors: TNFR-1 and TNFR-2. TNFR1 is ubiquitously expressed and can induce apoptosis through its intracellular death domain. Furthermore, TNF- $\alpha$ signaling through TNFR-1 under normal conditions leads to activation of the canonical NF- $\kappa \mathrm{B}$ pathway that regulates cell activation and differentiation (Chen and Goeddel, 2002; Sun, 2011). On the contrary, TNFR-2 expression is more restrained. This receptor does not have an intracellular death domain and rather induces $\mathrm{T}$ cell activation and proliferation (Grell et al., 1998) through the non-canonical NF- $\kappa$ B pathway (Sun, 2011). Furthermore, TNF$\alpha$ receptors are differentially expressed in Teffs and Tregs. In mice and men, Teff can rapidly upregulate TNFR-2 expression after TCR stimulation, but at the steady state only a very small proportion of Teffs expresses TNFR-2 (Valencia et al., 2006; Chen et al., 2007). In contrast, a significant proportion of Tregs expresses TNFR-2 at the steady state and can further increase its expression upon TCR stimulation or TNF- $\alpha$ incubation (Valencia et al., 2006; Chen et al., 2007). Hence, the dichotomic effect of TNF- $\alpha$ has been - at least in part - attributed to a pro-inflammatory action mediated by TNFR-1 on Teff cells and an anti-inflammatory effect mediated by TNFR-2 signaling on Tregs. However, although different biological functions can be assigned to the signals induced by each of the two receptors, confounding issues come from the existence of receptor crosstalk and shared actions, which are dependent on cell intrinsic and extrinsic factors (Faustman and Davis, 2010).

A likely role for TNF- $\alpha$ on tTreg development comes from TNFR-2 KO or TNFR-2 ligands-deficient (TNF- $\alpha /$ LT- $\alpha /$ LT- $\beta$ ) triple KO mice that show a decrease of Tregs in the thymus (Chen et al., 2013). These results need however to be interpreted with caution since lymphopenia per se or alterations of the thymic stromal architecture might affect tTreg generation. Further elucidation of the role of TNF- $\alpha$ and TNF receptors awaits the generation of mice with conditional ablation of TNF receptors in the Treg lineage.

Data on the effect of TNF- $\alpha$ on Treg function are fragmented and sometimes controversial. In vitro, TNF- $\alpha$ through TNFR-2 signaling increases mouse tTreg proliferation in the presence of IL-2 (Chen et al., 2007) and optimally activates Tregs increasing the expression of receptors of the TNF super family, such as TNFR-2, 4-1BB, and OX40 (Hamano et al., 2011). In addition, pre-incubation of Tregs with TNF- $\alpha$ can improve their in vitro suppressive function (Chen et al., 2007). However, Tregs obtained from WT or TNFR-2 KO mice appear to have similar in vitro suppressive activity (van Mierlo et al., 2008). Moreover, and at odds 
with mice results, TNF- $\alpha$ seems to reduce Treg suppressive function in humans (Valencia et al., 2006; Chen et al., 2007; Nagar et al., 2010; Zanin-Zhorov et al., 2010). The main issue of these experiments is that TNF- $\alpha$ can act on both Treg and Teff populations and that activated Teffs, which express TNFR-2, are less sensitive to Treg-mediated suppression (Chen and Oppenheim, 2010).

In vivo, TNF- $\alpha$ seems to contribute to Treg homeostasis (Chen et al., 2013; Chopra et al., 2013) and one paper implicates TNFR-2 and the non-canonical NF-kB pathway in this action (Rauert et al., 2010). Also, TNF- $\alpha$ seems to enhance Treg function in vivo, as suggested by our own results showing that activated Teffs can boost Treg proliferation and suppressive function, partly by a TNF- $\alpha$ mediated mechanism probably implying the non-canonical NF$\mathrm{kB}$ pathway (Grinberg-Bleyer et al., 2010b). Additionally, TNF- $\alpha$ could improve Treg proliferation and accumulation in mouse models of cecal ligation puncture, colitis, and cancer (Chen et al., 2007, 2013; Chopra et al., 2013). Moreover, the fact that TNF$\alpha^{-l-} \mathrm{LT}^{-l-} \mathrm{LT} \beta^{-1-}$ and TNFR- $2^{-1-}$ mice possess less Tregs in the periphery supports the idea that TNF- $\alpha$, like IL-2, plays a role in Treg homeostasis (Chen et al., 2013; Chopra et al., 2013). However, neither TNF- $\alpha^{-1-}$ nor TNFR-2 ${ }^{-1-}$ mice develop spontaneous autoimmunity and Tregs recovered from these mice express the same level of Foxp3 (Chen et al., 2013). Nevertheless, as the lack of TNFR-2 expression on Teffs could impact their pathogenicity, it is difficult to evaluate the individual contribution of the TNF$\alpha /$ TNFR-2 pathway to Treg and Teff function. Interestingly, recent work using transfer of highly purified WT or TNFR-2 KO Tregs in $\mathrm{RAG}^{-1-}$ mice suggests that colitis suppression could be dependent on TNFR-2 expression by Tregs in vivo (Housley et al., 2011; Chen et al., 2013). Collectively, these data point to an important role of signaling though TNFR-2 in the suppressive function of Tregs in vivo and calls for confirmation with the use of Tregs with conditional ablation of TNF receptors.

In humans, TNF- $\alpha$ has been implicated in the physiopathology of autoimmune diseases and consequently anti-TNF- $\alpha$ treatments (antibodies or soluble receptor) have been used with successful results obtained in Crohn's disease and rheumatoid arthritis (Chan and Carter, 2010). Interestingly, beyond dampening TNF- $\alpha$ 's proinflammatory effect, anti-TNF- $\alpha$ treatment has been associated with an accumulation of Tregs (Ehrenstein et al., 2004) and with improved Treg function (Ehrenstein et al., 2004; Valencia et al., 2006; Nadkarni et al., 2007). Likewise, a recent study showed that TNF- $\alpha$ present in the synovial fluid of RA patients reduced Treg suppressive function and this function was restored in anti-TNF- $\alpha$ treated patients (Nie et al., 2013). However, increased frequencies of Tregs, could be alternatively explained by a relative reduction of the activated Foxp3 $3^{-}$cells without a direct change in Treg homeostasis. Indeed, in mice transgenic for human TNF- $\alpha$, which develop spontaneous arthritis, both pools of Teffs and Tregs decrease during the disease course and increase during anti-TNF$\alpha$ treatment (Biton et al., 2011). Of note, not all patients respond to anti-TNF therapies and even some of them paradoxically develop anti-TNF-induced autoimmune diseases such as multiple sclerosis (MS), T1D, inflammatory bowel disease, vasculitis, lupus, and many others (Perez-Alvarez et al., 2013) suggesting that TNF- $\alpha$ could also have a regulatory role in other human autoimmune conditions. Although the underlying cause is not yet understood, some insight for the unexpected role of TNF- $\alpha$ in T1D and MS may be gained from the corresponding murine models. Indeed, TNF$\alpha$ can exacerbate T1D and EAE when administered early during disease initiation and can inhibit disease progression when administered at later time points (Ruddle et al., 1990; Willenborg et al., 1995; Wu et al., 2002). Therefore, it is possible that the opposite response to anti-TNF therapies originates from the opposite roles that TNF may have during the different phases of the disease.

\section{PERIPHERALLY DERIVED-REGULATORY T CELLS}

The group of J. Lafaille was among the first to described pTregs in 2002. They showed that the transfer of $\mathrm{CD}^{+}$spleen $\mathrm{T}$ cells could prevent EAE in an IL-2-dependent process involving the differentiation of $\mathrm{CD}^{+} \mathrm{CD} 25^{+}$Tregs from $\mathrm{CD} 4^{+} \mathrm{CD} 25^{-} \mathrm{T}$ cell precursors (Furtado et al., 2002). Induced from naïve $\mathrm{CD} 4^{+} \mathrm{T}$ cells in the periphery, $\mathrm{p}$ Tregs present a distinct and broader TCR repertoire than tTreg (Haribhai et al., 2011; Josefowicz et al., 2012b). Indeed, pTreg differentiation mainly occurs in the context of bacterial or viral infection (Robertson et al., 2006; Curotto de Lafaille and Lafaille, 2009; Ertelt et al., 2009), in tumors (Nishikawa et al., 2003; Liu et al., 2007), or in mucosal tissues notably in a context of oral tolerance (Mucida et al., 2005; Coombes et al., 2007; Sun et al., 2007; Josefowicz et al., 2012a). A recent study suggested that pTreg main function would be the prevention of mucosal Th2-mediated immunity, notably in the gastrointestinal tract and lungs (Josefowicz et al., 2012a). pTregs would also be involved in the induction of tolerance to commensal microbiota (Sun et al., 2007; Josefowicz et al., 2012a).

The differentiation of pTregs requires antigenic stimulation in a defined anti-inflammatory environment, process orchestrated in part by dendritic cells (DC). Several DC subsets have been associated with pTreg induction (Yamazaki et al., 2007), including plasmacytoid DC (Ochando et al., 2006; Goubier et al., 2008) and $\mathrm{CD}_{103^{+}} \mathrm{DCs}$, which following education by retinoic acid (RA) differentiate into tolerogenic DC, mainly in the intestine (Coombes et al., 2007; Sun et al., 2007). H. Von Boehmer's group showed that targeting the antigen toward DCs through DEC205 recognition induced the conversion of $\mathrm{CD}^{+}$naïve $\mathrm{T}$ cells into $\mathrm{CD} 4{ }^{+} \mathrm{CD} 25^{+}$Foxp $^{+}{ }^{+}$pTreg (Kretschmer et al., 2005). This induction was shown to be dependent on TGF- $\beta$ (Yamazaki et al., 2008). Indeed, mice deficient for TGF- $\beta$ in Langerhans cells (a specialized subset of DC in the skin) develop signs of skin auto immunity (Kaplan et al., 2007), in agreement with the hypothesis that a lack of DC in the skin may lead to local auto-immunity due to a defect in Treg. The role of IL- 2 or TNF- $\alpha$ produced by DC in the induction of pTreg remains to be fully elucidated.

\section{TGF- $\beta$ IS THE MASTER REGULATOR OF pTreg DIFFERENTIATION AND HOMEOSTASIS}

The differentiation of $\mathrm{p}$ Tregs from $\mathrm{CD} 4^{+} \mathrm{CD} 25^{-}$Foxp $3^{-}$naive $\mathrm{T}$ cells requires TGF- $\beta$. Initial studies showed that in vitro treatment of murine or human $\mathrm{CD} 4^{+} \mathrm{CD} 25^{-} \mathrm{Foxp}^{-}$naive $\mathrm{T}$ cells with TGF- $\beta$ induced Foxp3 expression in these cells and conferred a suppressive function (Chen et al., 2003; Walker et al., 2003). Then, a prominent role for TGF- $\beta$ in pTreg differentiation has been demonstrated in vivo (Marie et al., 2005, 2006; Coombes et al., 2007; Sun et al., 2007), notably in the context of oral tolerance 
(Curotto de Lafaille and Lafaille, 2009). In addition, mice deficient for the TGF- $\beta$-sensitive CNS1 enhancer do not present any differentiation of pTregs (Zheng et al., 2010; Josefowicz et al., 2012a) confirming the essential role of TGF- $\beta$ in pTreg induction. Interestingly, in vivo pTregs differentiation by TGF- $\beta$ can occur both in physiological (Coombes et al., 2007; Sun et al., 2007) and pathological (Grainger et al., 2010) situations.

Two kinds of regulators of pTreg differentiation can be distinguished. First, those that interfere with TGF- $\beta$ signaling like TNF- $\alpha$ (Zhang and Bevan, 2012), or those that induce PI3K signaling. Of importance, the PI3K/Akt/mTOR pathway is a strong inhibitor of Foxp3 expression, which prevents both tTreg and pTreg differentiation (Haxhinasto et al., 2008; Sauer et al., 2008). Consistent with these observations, a very recent study demonstrated that pTreg differentiation could not occur in presence of the C3a or C5a signaling pathway. This pathway blocks Foxp3 expression by induction of PI3K signaling and repression of TGF- $\beta$ expression (Strainic et al., 2013). Second, pTreg differentiation can be improved by molecules that increase TGF- $\beta$ signaling (Xu et al., 2010), like CTLA-4 (Karman et al., 2012). Thus, modulating TGF$\beta$ or PI3K signaling in the periphery might represent a promising approach to tip the balance in favor of pTreg.

Of importance, TGF- $\beta$ has a dual and opposite role in the immune system: it participates not only in the generation of pTregs, but also, in conjunction with IL-6 or IL-4, induces the differentiation of pro-inflammatory Th17 cells or Th9 cells, respectively (Jabeen and Kaplan, 2012; Maddur et al., 2012). Consequently, TGF- $\beta$ administration could aggravate inflammation and autoimmunity. Moreover, TGF- $\beta$ pleiotropic effects outside the immune system and toxicity limit its therapeutic application (Flanders and Roberts, 2001) and systemic administration of TGF$\beta$ has been rapidly abandoned by the pharmaceutical industry (Prud'Homme, 2007).

\section{IL-2 SIGNALING IS MANDATORY FOR pTreg DIFFERENTIATION, HOMEOSTASIS AND STABILITY}

Although IL-2 by itself is not sufficient to generate pTregs, it seems to be critical for the development of functional $\mathrm{CD} 4{ }^{+} \mathrm{CD} 25^{+}$Foxp $3^{+}$p Tregs induced by TGF- $\beta$ (Chen et al., 2003; Davidson et al., 2007; Zheng et al., 2007). Indeed, addition of a neutralizing anti-IL-2 antibody to the culture strikingly abolishes the induction of Foxp3, and IL- $2^{-1-}$ or Stat $5^{-1-}$ naïve T cells are unable to generate pTregs (Davidson et al., 2007; Laurence et al., 2007; Yao et al., 2007; Zheng et al., 2007). Interestingly, the role of IL-2 is non-redundant, as other common gamma chain receptor using cytokines cannot restore pTreg generation in IL-2 ${ }^{-/}-\mathrm{T}$ cells (Davidson et al., 2007; Zheng et al., 2007). Likewise, the group of D. Horwitz reported that IL-2 also potentiates $\mathrm{p}$ Treg suppressive function and expression of key Tregsignature molecules such as CTLA-4, GITR, and CD122 (Zheng et al., 2007). Different mechanisms have been proposed to explain IL- 2 action in the TGF- $\beta$ mediated induction system: sustained Foxp3 expression via JAK3/STAT5 signaling (Chen et al., 2011), enhancement of proliferation and survival of newly generated pTregs, or increased conversion of latent to active TGF- $\beta$ via the urokinase receptor pathway (Nykjaer et al., 1994; Odekon et al., 1994).
In the case of lymphopenic recipients, the generation of pTregs upon transfer of naive $\mathrm{T}$ cells seems dependent on IL-2 production by activated T cells (Knoechel et al., 2005). Along these lines, low-dose IL-2 injection into irradiated recipients of allogeneic T cells increases the generation of donor-derived pTregs (Shin et al., 2011). However, the specific contribution of tTregs and pTregs to the Treg increase induced by exogenous IL-2 administration to lympho-replete mice is still unexplored (Tang et al., 2008; Webster et al., 2009; Grinberg-Bleyer et al., 2010a).

In vitro and in vivo recently differentiated pTregs present unstable Foxp3 expression (Floess et al., 2007; Miyao et al., 2012), which can be lost in an inflammatory context, giving rise to "exTregs" producing pro-inflammatory cytokines (Zhou et al., 2009). Importantly, in most of the studies describing Foxp3 instability, Tregs were put in an environment lacking IL-2 (Tang et al., 2008; Duarte et al., 2009; Oldenhove et al., 2009; Zhou et al., 2009). However, IL-2 administration could prevent the conversion of Tregs (Tang et al., 2008; Duarte et al., 2009; Oldenhove et al., 2009; Zhou et al., 2009). Furthermore, unstable pTregs are exclusively located in the $\mathrm{CD} 4^{+} \mathrm{CD} 25^{-}$Foxp $3^{\text {low }}$ compartment and, upon time and "education," they acquire increased CD25 and Foxp3 expression as well as a demethylated CNS2 - a well known marker of Treg stability (Floess et al., 2007; Polansky et al., 2008; Komatsu et al., 2009; Miyao et al., 2012). Also, IL-2 could prevent conversion of recently differentiated pTregs by the induction and regulation of GATA-3 expression (Wang et al., 2011; Wohlfert et al., 2011). Taken together, all these studies suggest that IL-2 plays an important role in the "education" of pTregs (Figure 2). However, further studies are required to determine the additional factors involved in the stability of the Treg lineage.

\section{THE EMERGING ROLE OF TNF- $\alpha$ IN pTreg HOMEOSTASIS AND FUNCTION}

Interestingly, Housley et al. (2011) point out that pTregs, contrary to tTregs, may not require TNFR-2 expression to suppress in vivo. However, TGF- $\beta$ pre-incubation can render tTregs from TNFR$2^{-l-}$ mice as efficient as WT cells, suggesting that in this study, the implication of TNFR-2 in the suppressive capacity of pTregs may be hidden by the TGF- $\beta$ pre-incubation (Housley et al., 2011). Consequently, the role of TNFR-2 in the suppressive function of pTregs is still unclear.

In humans, the above-described observation that blocking TNF- $\alpha$ is associated with an increase of Tregs (Ehrenstein et al., 2004) can alternatively be explained by the fact that TNF- $\alpha$ exposure could hamper pTreg induction. Indeed, it is not clear whether the accumulated Tregs observed after anti-TNF- $\alpha$ treatment are tTreg or pTreg. Then, it could be possible that TNF- $\alpha$ may have a negative effect on the induction of pTreg cells that would be removed during anti-TNF- $\alpha$ administration. Indeed, it was shown that blocking TNF- $\alpha$ increased susceptibility to Histoplasma capsulatum infection and induced a population of CD $4{ }^{+} \mathrm{CD} 25^{+} \mathrm{T}$ cells possessing IL-10-dependent suppressive function in mice (Deepe and Gibbons, 2008). Besides, TNF- $\alpha$ can inhibit TGF- $\beta$-driven pTreg induction from Foxp $3^{-}$Teffs in an EAE model (Zhang et al., 2013). Finally, it has been pointed out that soluble TNF- $\alpha$ and membrane-bound TNF- $\alpha$ may differently affect the process of pTreg induction in vitro (Kleijwegt et al., 2010). A better knowledge 


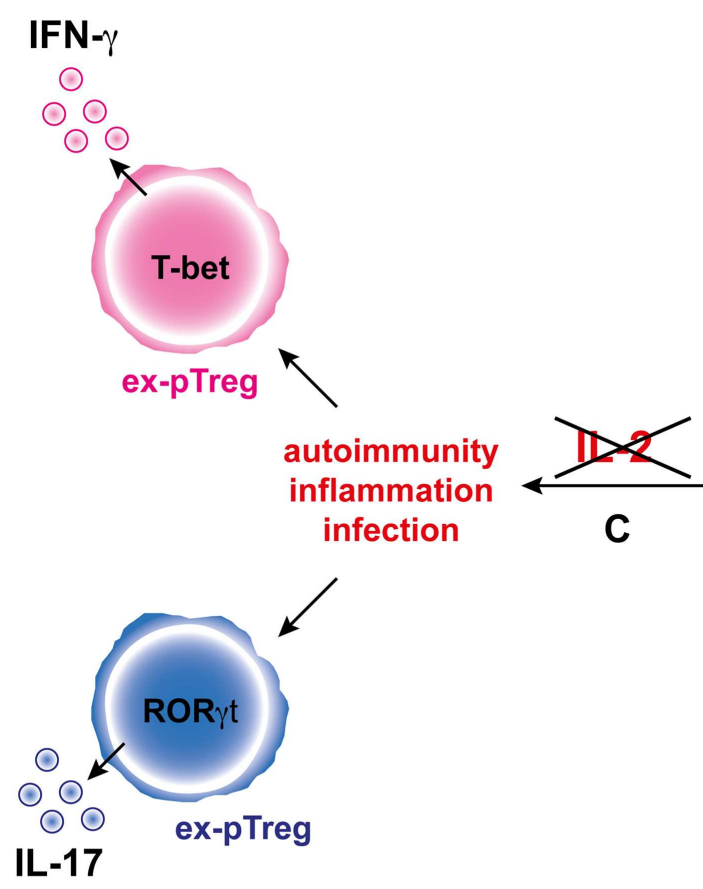

FIGURE 2 | IL-2 favors the generation and increases the stability of the pTreg phenotype. (A) Activation of a naive conventional T cells through TCR stimulation and in the presence of TGF- $\beta$ leads to generation of unstable pTregs that express moderate levels of Foxp3 and CD25. (B) In the presence of IL-2, pTregs increase the expression

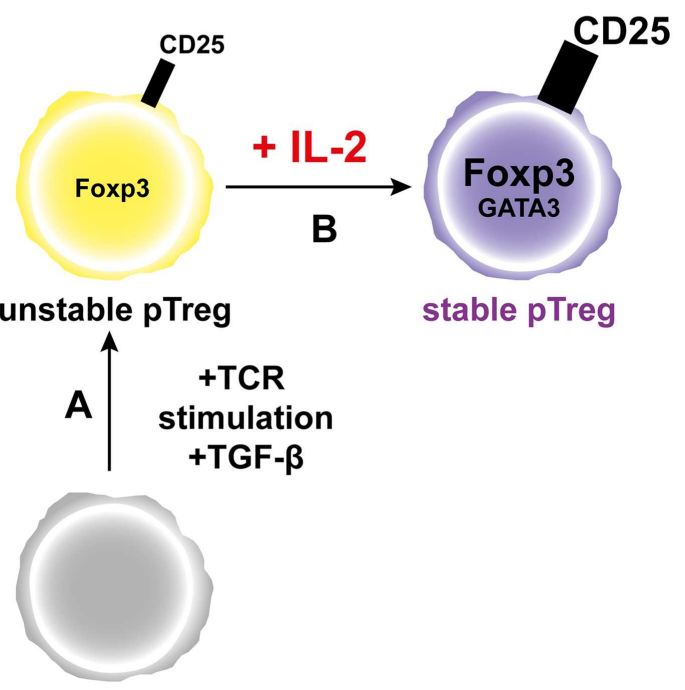

naive Tconv

of the mechanisms ruling expression of TNFR-1 and TNFR-2 on tTregs and pTregs could help explain potential different effects of TNF- $\alpha$ on these two cell populations.

\section{CONCLUDING REMARKS}

We focused our review on three major cytokines that regulate different aspects of Treg biology, namely IL-2, TGF- $\beta$, and TNF- $\alpha$, because they are of great fundamental and clinical importance. Indeed, immunotherapies based on a better knowledge of the impact of cytokines on Treg biology are emerging (Chan and Carter, 2010; Koreth et al., 2011; Saadoun et al., 2011). However, we need to better understand the division of labor of pTreg and tTreg in the fine tuning of the immune response. It is not yet clear if each cell type acts preferentially at different localizations, at different timepoints during the initiation, expansion, contraction, and memory generation

\section{REFERENCES}

Almeida, A. R., Zaragoza, B., and Freitas, A. A. (2006). Indexation as a novel mechanism of lymphocyte homeostasis: the number of $\mathrm{CD} 4+\mathrm{CD} 25+$ regulatory $\mathrm{T}$ cells is indexed to the number of
IL-2-producing cells. J. Immunol. 177, 192-200.

Biton, J., Semerano, L., Delavallee, L., Lemeiter, D., Laborie, M., Grouard-Vogel, G., et al. (2011). Interplay between TNF and regulatory $\mathrm{T}$ cells in a TNF-driven levels of Foxp3 and CD25 and the pTreg phenotype is stabilized. (C) During inflammation and in the absence of IL-2, the pTregs convert into "ex-pTregs" that can produce different pro-inflammatory cytokines, such as IFN- $\gamma$ or IL-17 depending on the environmental context.

of the immune response, or has specific targets for suppression. Also, we need to dissect the specific cytokine requirements for tTreg and pTreg generation, homeostasis and function, which are sometimes distinct and sometimes shared. Only with that information at hands will the extraordinary promises of tTregs and pTregs be fully exploited in safe and effective clinical applications.

\section{ACKNOWLEDGMENTS}

We would like to thank Pablo Flaiszman for the artistic work on the figures. Jérémie David Goldstein, Louis Pérol, and Audrey Baeyens were supported by the Ministère de l'Enseignement Supérieur et de la Recherche and Bruno Zaragoza by the Université Pierre et Marie Curie, Paris 06. This work was supported by the EFSD/JDRF/NN 2011 and INSERM/DGOS 2011 (to Eliane Piaggio), and by ANRS (to Gilles Marodon).

murine model of arthritis. J. Immunol. 186, 3899-3910. doi:10.4049/jimmunol.1003372

Bottini, N., Musumeci, L., Alonso, A., Rahmouni, S., Nika, K., Rostamkhani, M., et al. (2004). A functional variant of lymphoid tyrosine phosphatase is associated with type I diabetes. Nat. Genet. 36, 337-338. doi:10.1038/ng1323

Burchill, M. A., Yang, J., Vang, K. B., Moon, J. J., Chu, H. H., Lio, C. W., et al. (2008). Linked T cell receptor and cytokine signaling govern the 
development of the regulatory $\mathrm{T}$ cell repertoire. Immunity 28 , 112-121. doi:10.1016/j.immuni. 2007.11.022

Burchill, M. A., Yang, J., Vogtenhuber, C., Blazar, B. R., and Farrar, M. A. (2007). IL-2 receptor beta-dependent STAT5 activation is required for the development of Foxp3( regulatory T cells. J. Immunol. 178, 280-290.

Chan, A. C., and Carter, P. J. (2010). Therapeutic antibodies for autoimmunity and inflammation. Nat. Rev. Immunol. 10, 301-316. doi:10.1038/nri2761

Chen, G., and Goeddel, D. V. (2002). TNF-R1 signaling: a beautiful pathway. Science 296, 1634-1635. doi:10.1126/science.1071924

Chen, Q., Kim, Y. C., Laurence, A., Punkosdy, G. A., and Shevach, E. M. (2011). IL-2 controls the stability of Foxp3 expression in TGF-beta-induced Foxp3+ T cells in vivo. J. Immunol. 186, 6329-6337. doi:10.4049/jimmunol.1100061

Chen, W., Jin, W., Hardegen, N., Lei, K. J., Li, L., Marinos, N., et al. (2003). Conversion of peripheral $\mathrm{CD} 4+\mathrm{CD} 25-$ naive $\mathrm{T}$ cells to $\mathrm{CD} 4+\mathrm{CD} 25+$ regulatory $\mathrm{T}$ cells by TGF-beta induction of transcription factor Foxp3. J. Exp. Med. 198, 1875-1886. doi:10.1084/jem.20030152

Chen, X., Baumel, M., Mannel, D. N., Howard, O. M., and Oppenheim, J. J. (2007). Interaction of TNF with TNF receptor type 2 promotes expansion and function of mouse CD4+CD25+ T regulatory cells. $J$. Immunol. 179, 154-161.

Chen, X., and Oppenheim, J. J. (2010). TNF-alpha: an activator of CD4+FoxP3+TNFR2+ regulatory T cells. Curr. Dir. Autoimmun. 11, 119-134. doi:10.1159/000289201

Chen, X., Wu, X., Zhou, Q., Howard, O. M., Netea, M. G., and Oppenheim, J. J. (2013). TNFR2 is critical for the stabilization of the CD4+Foxp3+ regulatory $T$. cell phenotype in the inflammatory environment. J. Immunol. 190, 1076-1084. doi:10.4049/jimmunol.1202659

Chopra, M., Riedel, S. S., Biehl, M., Krieger, S., von Krosigk, V., Bauerlein, C. A., et al. (2013). Tumor necrosis factor receptor 2dependent homeostasis of regulatory $\mathrm{T}$ cells as a player in TNF-induced experimental metastasis. Carcinogenesis 34, 1296-1303. doi:10.1093/carcin/bgt038

Coombes, J. L., Siddiqui, K. R., Arancibia-Carcamo, C. V., Hall, J., Sun, C. M., Belkaid, Y., et al. (2007). A functionally specialized population of mucosal CD103+ DCs induces Foxp3+ regulatory $\mathrm{T}$ cells via a TGF-beta and retinoic acid-dependent mechanism. J. Exp. Med. 204, 1757-1764. doi:10.1084/jem.20070590

Curotto de Lafaille, M. A., and Lafaille, J. J. (2009). Natural and adaptive foxp3+ regulatory $\mathrm{T}$ cells: more of the same or a division of labor? Immunity 30, 626-635. doi:10.1016/j.immuni

Davidson, T. S., DiPaolo, R. J., Andersson, J., and Shevach, E. M. (2007). Cutting Edge: IL-2 is essential for TGF-beta-mediated induction of Foxp3+ $\mathrm{T}$ regulatory cells. J. Immunol. 178, 4022-4026.

D'Cruz, L. M., and Klein, L. (2005). Development and function of agonist-induced CD25+Foxp3+ regulatory $\mathrm{T}$ cells in the absence of interleukin 2 signaling. Nat. Immunol. 6, 1152-1159. doi:10.1038/ni1264

Deepe, G. S. Jr., and Gibbons, R. S. (2008). TNF-alpha antagonism generates a population of antigenspecific $\mathrm{CD} 4+\mathrm{CD} 25+\mathrm{T}$ cells that inhibit protective immunity in murine histoplasmosis. J. Immunol. 180, 1088-1097.

Dinh, T. N., Kyaw, T. S., Kanellakis, P., To, K., Tipping, P., Toh, B. H., et al. (2012). Cytokine therapy with interleukin2/anti-interleukin-2 monoclonal antibody complexes expands CD4+CD25+Foxp3+ regulatory $\mathrm{T}$ cells and attenuates development and progression of atherosclerosis. Circulation 126, 1256-1266. doi:10.1161/CIRCULATIONAHA. 112.099044

Duarte, J. H., Zelenay, S., Bergman, M. L., Martins, A. C., and Demengeot, J. (2009). Natural Treg cells spontaneously differentiate into pathogenic helper cells in lymphopenic conditions. Eur. J. Immunol. 39, 948-955. doi:10.1002/eji.200839196 Ehrenstein, M. R., Evans, J. G., Singh, A., Moore, S., Warnes, G., Isenberg, D. A., et al. (2004). Compromised function of regulatory $\mathrm{T}$ cells in rheumatoid arthritis and reversal by anti-TNFalpha therapy. J. Exp. Med. 200, 277-285. doi:10.1084/jem.2004 0165

Ertelt, J. M., Rowe, J. H., Johanns, T. M., Lai, J. C., McLachlan, J. B. and Way, S. S. (2009). Selective priming and expansion of antigenspecific Foxp3- CD4+ T cells during Listeria monocytogenes infection. J. Immunol. 182, 3032-3038. doi:10.4049/jimmunol.0803402
Fahlen, L., Read, S., Gorelik, L., Hurst, S. D., Coffman, R. L., Flavell, R. A., et al. (2005). T cells that cannot respond to TGF-beta escape control by $\mathrm{CD} 4(+) \mathrm{CD} 25(+)$ regulatory T cells. J. Exp. Med. 201, 737-746. doi:10.1084/jem.20040685

Faustman, D., and Davis, M. (2010). TNF receptor 2 pathway: drug target for autoimmune diseases. Nat. Rev. Drug Discov. 9, 482-493. doi:10.1038/nrd3030

Flanders, K. C., and Roberts, A. B. (2001). "TGF-+," in Cytokine Reference, Vol. 1, eds J. J. Oppenheim and M. Feldmann (San Diego, CA: Academic Press), 719-746.

Floess, S., Freyer, J., Siewert, C., Baron, U., Olek, S., Polansky, J., et al. (2007). Epigenetic control of the foxp3 locus in regulatory $\mathrm{T}$ cells. PLoS Biol. 5:e38. doi:10.1371/journal.pbio.0050038

Fontenot, J. D., Dooley, J. L., Farr, A. G., and Rudensky, A. Y. (2005a). Developmental regulation of Foxp3 expression during ontogeny. J. Exp. Med. 202, 901-906. doi:10.1084/jem.20050784

Fontenot, J. D., Rasmussen, J. P., Gavin, M. A., and Rudensky, A. Y. (2005b). A function for interleukin 2 in Foxp3-expressing regulatory $\mathrm{T}$ cells. Nat. Immunol. 6, 1142-1151. doi:10.1038/ni1263

Fontenot, J. D., Gavin, M. A., and Rudensky, A. Y. (2003). Foxp3 programs the development and function of $\mathrm{CD} 4+\mathrm{CD} 25+$ regulatory $\mathrm{T}$ cells. Nat. Immunol. 4, 330-336. doi:10.1038/ni904

Furtado, G. C., Curotto de Lafaille, M. A., Kutchukhidze, N., and Lafaille, J. J. (2002). Interleukin 2 signaling is required for $\mathrm{CD} 4(+)$ regulatory T cell function. J. Exp. Med. 196, 851-857. doi:10.1084/jem.20020190

Gavin, M. A., Rasmussen, J. P., Fontenot, J. D., Vasta, V., Manganiello, V. C., Beavo, J. A., et al. (2007). Foxp3dependent programme of regulatory T-cell differentiation. Nature 445, 771-775. doi:10.1038/nature05543

Goldstein, J. D., Balderas, R. S., and Marodon, G. (2011). Continuous activation of the CD122/STAT5 signaling pathway during selection of antigen-specific regulatory $\mathrm{T}$ cells in the murine thymus. PLoS ONE 6:e19038. doi:10.1371/journal.pone.0019038

Gorelik, L., and Flavell, R. A. (2000). Abrogation of TGFbeta signaling in $\mathrm{T}$ cells leads to spontaneous $\mathrm{T}$ cell differentiation and autoimmune disease. Immunity 12, 171-181. doi:10 1016/S1074-7613(00)80170-3
Goubier, A., Dubois, B., Gheit, H., Joubert, G., Villard-Truc, F., Asselin-Paturel, C., et al. (2008). Plasmacytoid dendritic cells mediate oral tolerance. Immunity 29, 464-475. doi:10.1016/j.immuni.2008.06.017

Grainger, J. R., Smith, K. A., Hewitson, J. P., McSorley, H. J., Harcus, Y., Filbey, K. J., et al. (2010). Helminth secretions induce de novo $\mathrm{T}$ cell Foxp3 expression and regulatory function through the TGF-beta pathway. J. Exp. Med. 207, 2331-2341. doi:10.1084/jem.20101074

Grell, M., Becke, F. M., Wajant, H., Mannel, D. N., and Scheurich, P. (1998). TNF receptor type 2 mediates thymocyte proliferation independently of TNF receptor type 1. Eur. J. Immunol. 28, 257-263. doi:10.1002/(SICI)15214141(199801)28:01<257::AIDIMMU257>3.0.CO;2-G

Grinberg-Bleyer, Y., Baeyens, A., You, S., Elhage, R., Fourcade, G., Gregoire, S., et al. (2010a). IL-2 reverses established type 1 diabetes in NOD mice by a local effect on pancreatic regulatory $\mathrm{T}$ cells. J. Exp. Med. 207, 1871-1878. doi:10.1084/jem.20100209

Grinberg-Bleyer, Y., Saadoun, D., Baeyens, A., Billiard, F., Goldstein, J. D., Gregoire, S., et al. (2010b) Pathogenic $\mathrm{T}$ cells have a paradoxical protective effect in murine autoimmune diabetes by boosting Tregs. J. Clin. Invest. 120, 4558-4568. doi:10.1172/JCI42945

Hamano, R., Huang, J., Yoshimura, T., Oppenheim, J. J., and Chen, X. (2011). TNF optimally activatives regulatory $\mathrm{T}$ cells by inducing TNF receptor superfamily members TNFR2, 4-1BB and OX40. Eur. J. Immunol. 41, 2010-2020. doi:10.1002/eji.201041205

Haribhai, D., Williams, J. B., Jia, S., Nickerson, D., Schmitt, E. G., Edwards, B., et al. (2011). A requisite role for induced regulatory $\mathrm{T}$ cells in tolerance based on expanding antigen receptor diversity. Immunity 35, 109-122. doi:10.1016/j.immuni.2011.03.029

Haxhinasto, S., Mathis, D., and Benoist, C. (2008). The AKTmTOR axis regulates de novo differentiation of CD4+Foxp3+ cells. J. Exp. Med. 205, 565-574. doi:10.1084/jem.20071477

Hill, J. A., Feuerer, M., Tash, K., Haxhinasto, S., Perez, J., Melamed, R., et al. (2007). Foxp3 transcription-factor-dependent and -independent regulation of the regulatory $\mathrm{T}$ cell transcriptional 
signature. Immunity 27, 786-800. doi:10.1016/j.immuni.2007.09.010

Hori, S., Nomura, T., and Sakaguchi, S. (2003). Control of regulatory $\mathrm{T}$ cell development by the transcription factor Foxp3. Science 299, 1057-1061. doi:10.1126/science. 1079490

Housley, W. J., Adams, C. O., Nichols, F. C., Puddington, L., Lingenheld, E. G., Zhu, L., et al. (2011). Natural but not inducible regulatory $\mathrm{T}$ cells require TNFalpha signaling for in vivo function. J. Immunol. 186, 6779-6787. doi:10.4049/jimmunol.1003868

Hsieh, C. S., Zheng, Y., Liang, Y., Fontenot, J. D., and Rudensky, A. Y. (2006). An intersection between the self-reactive regulatory and nonregulatory $\mathrm{T}$ cell receptor repertoires. Nat. Immunol. 7, 401-410. doi:10.1038/ni1318

Itoh, M., Takahashi, T., Sakaguchi, N., Kuniyasu, Y., Shimizu, J., Otsuka, F., et al. (1999). Thymus and autoimmunity: production of CD25+CD4+ naturally anergic and suppressive $\mathrm{T}$ cells as a key function of the thymus in maintaining immunologic self-tolerance. $J$. Immunol. 162, 5317-5326.

Jabeen, R., and Kaplan, M. H. (2012). The symphony of the ninth: the development and function of Th9 cells. Curr. Opin. Immunol. 24, 303-307. doi:10.1016/j.coi.2012.02.001

Jacob, C. O., and McDevitt, H. O. (1988). Tumour necrosis factoralpha in murine autoimmune 'lupus' nephritis. Nature 331, 356-358. doi:10.1038/331356a0

Jordan, M. S., Boesteanu, A., Reed, A. J., Petrone, A. L., Holenbeck, A. E., Lerman, M. A., et al. (2001). Thymic selection of $\mathrm{CD} 4+\mathrm{CD} 25+$ regulatory $\mathrm{T}$ cells induced by an agonist self-peptide. Nat. Immunol. 2, 301-306. doi:10.1038/86302

Josefowicz, S. Z., Niec, R. E., Kim, H. Y., Treuting, P., Chinen, T., Zheng, Y., et al. (2012a). Extrathymically generated regulatory $\mathrm{T}$ cells control mucosal TH2 inflammation. Nature 482, 395-399. doi:10.1038/nature10772

Josefowicz, S. Z., Lu, L. F., and Rudensky, A. Y. (2012b). Regulatory $\mathrm{T}$ cells: mechanisms of differentiation and function. Annu. Rev. Immunol. 30, 531-564. doi:10.1146/annurev.immunol.25. 022106.141623

Kaplan, D. H., Li, M. O., Jenison, M. C., Shlomchik, W. D., Flavell, R. A., and Shlomchik, M. J. (2007). Autocrine/paracrine
TGFbetal is required for the development of epidermal Langerhans cells. J. Exp. Med. 204, 2545-2552. doi:10.1084/jem.20071401

Karman, J., Jiang, J. L., Gumlaw, N., Zhao, H., Campos-Rivera, J., Sancho, J., et al. (2012). Ligation of cytotoxic $\mathrm{T}$ lymphocyte antigen-4 to $\mathrm{T}$ cell receptor inhibits $\mathrm{T}$ cell activation and directs differentiation into Foxp3+ regulatory T cells. J. Biol. Chem. 287, 11098-11107. doi:10.1074/jbc.M111.283705

Kleijwegt, F. S., Laban, S., Duinkerken, G., Joosten, A. M., Zaldumbide, A., Nikolic, T., et al. (2010). Critical role for TNF in the induction of human antigen-specific regulatory $\mathrm{T}$ cells by tolerogenic dendritic cells. J. Immunol. 185, 1412-1418. doi:10.4049/jimmunol.1000560

Knoechel, B., Lohr, J., Kahn, E., Bluestone, J. A., and Abbas, A. K. (2005). Sequential development of interleukin 2-dependent effector and regulatory $\mathrm{T}$ cells in response to endogenous systemic antigen. J. Exp. Med. 202, 1375-1386. doi:10.1084/jem.20050855

Komatsu, N., Mariotti-Ferrandiz, M. E., Wang, Y., Malissen, B., Waldmann, H., and Hori, S. (2009). Heterogeneity of natural Foxp3 + T cells: a committed regulatory T-cell lineage and an uncommitted minor population retaining plasticity. Proc. Natl. Acad. Sci. U.S.A. 106, 1903-1908. doi:10.1073/pnas.0811556106

Koreth, J., Matsuoka, K., Kim, H. T., McDonough, S. M., Bindra, B., Alyea, E. P. III, et al. (2011). Interleukin-2 and regulatory $\mathrm{T}$ cells in graft-versus-host disease. N. Engl. J. Med. 365, 2055-2066. doi:10.1056/NEJMoa1 108188

Kretschmer, K., Apostolou, I., Hawiger, D., Khazaie, K., Nussenzweig, M. C., and von Boehmer, H. (2005). Inducing and expanding regulatory $\mathrm{T}$ cell populations by foreign antigen. Nat. Immunol. 6, 1219-1227. doi:10.1038/ni1265

Laurence, A., Tato, C. M., Davidson, T. S., Kanno, Y., Chen, Z., Yao, Z., et al. (2007). Interleukin-2 signaling via STAT5 constrains T helper 17 cell generation. Immunity 26, 371-381. doi:10.1016/j.immuni.2007.02.009

Leveen, P., Larsson, J., Ehinger, M., Cilio, C. M., Sundler, M., Sjostrand, L. J., et al. (2002). Induced disruption of the transforming growth factor beta type II receptor gene in mice causes a lethal inflammatory disorder that is transplantable. Blood 100, 560-568. doi:10.1182/blood.V100.2.560

Li, M. O., Sanjabi, S., and Flavell, R. A. (2006). Transforming growth factor-beta controls development, homeostasis, and tolerance of T cells by regulatory $\mathrm{T}$ cell-dependent and -independent mechanisms. Immunity 25, 455-471. doi:10.1016/j.immuni.2006.07.011

Lin, W., Haribhai, D., Relland, L. M., Truong, N., Carlson, M. R., Williams, C. B., et al. (2007). Regulatory T cell development in the absence of functional Foxp3. Nat. Immunol. 8, 359-368. doi:10.1038/ni1445

Lio, C. W., and Hsieh, C. S. (2008) A two-step process for thymic regulatory $\mathrm{T}$ cell development. Immunity 28, 100-111. doi:10.1016/j.immuni.2007.11.021

Liston, A., Enders, A., and Siggs, O. M. (2008). Unravelling the association of partial T-cell immunodeficiency and immune dysregulation. Nat. Rev. Immunol. 8, 545-558. doi:10.1038/nri2336

Liston, A., Siggs, O. M., and Goodnow, C. C. (2007). Tracing the action of IL-2 in tolerance to islet-specific antigen. Immunol. Cell Biol. 85, 338-342. doi:10.1038/sj.icb.7100049

Liu, V. C., Wong, L. Y., Jang, T., Shah, A. H., Park, I., Yang, X., et al. (2007). Tumor evasion of the immune system by converting CD4+CD25- T cells into $\mathrm{CD} 4+\mathrm{CD} 25+\mathrm{T}$ regulatory cells: role of tumor-derived TGFbeta. J. Immunol. 178, 2883-2892.

Liu, Y., Zhang, P., Li, J., Kulkarni, A. B., Perruche, S., and Chen, W. (2008). A critical function for TGF-beta signaling in the development of natural CD4+CD25+Foxp3+ regulatory T cells. Nat. Immunol. 9, 632-640. doi:10.1038/ni.1607

Maddur, M. S., Miossec, P., Kaveri, S. V., and Bayry, J. (2012). Th17 cells: biology, pathogenesis of autoimmune and inflammatory diseases, and therapeutic strategies. Am. J. Pathol. 181, 8-18. doi:10.1016/j.ajpath.2012.03.044

Marie, J. C., Letterio, J. J., Gavin, M., and Rudensky, A. Y. (2005). TGF-betal maintains suppressor function and Foxp3 expression in CD4+CD25+ regulatory $\mathrm{T}$ cells. J. Exp. Med. 201, 1061-1067. doi:10.1084/jem.20042276

Marie, J. C., Liggitt, D., and Rudensky, A. Y. (2006). Cellular mechanisms of fatal early-onset autoimmunity in mice with the $\mathrm{T}$ cell-specific targeting of transforming growth factor-beta receptor. Immunity 25, 441-454. doi:10.1016/j.immuni.2006.07.012

Merkenschlager, M., and von Boehmer, H. (2010). PI3 kinase signalling blocks Foxp3 expression by sequestering Foxo factors. J.
Exp. Med. 207, 1347-1350. doi:10.1084/jem.20101156

Miyao, T., Floess, S., Setoguchi, R., Luche, H., Fehling, H. J., Waldmann, H., et al. (2012). Plasticity of Foxp3(+) T cells reflects promiscuous Foxp3 expression in conventional $\mathrm{T}$ cells but not reprogramming of regulatory $\mathrm{T}$ cells. Immunity 36, 262-275. doi:10.1016/j.immuni.2011.12.012

Mouly, E., Chemin, K., Nguyen, H. V., Chopin, M., Mesnard, L., Leitede-Moraes, M., et al. (2010). The Ets-1 transcription factor controls the development and function of natural regulatory $\mathrm{T}$ cells. J. Exp. Med. 207, 2113-2125. doi:10.1084/jem.20092153

Mucida, D., Kutchukhidze, N., Erazo, A., Russo, M., Lafaille, J. J., and Curotto de Lafaille, M. A. (2005). Oral tolerance in the absence of naturally occurring Tregs. J. Clin. Invest. 115, 1923-1933. doi:10.1172/JCI24487

Murawski, M. R., Litherland, S. A., Clare-Salzler, M. J., and Davoodi-Semiromi, A. (2006). Upregulation of Foxp3 expression in mouse and human Treg is IL2/STAT5 dependent: implications for the NOD STAT5B mutation in diabetes pathogenesis. Ann. N. Y. Acad. Sci. 1079, 198-204. doi:10.1196/annals.1375.031

Nadkarni, S., Mauri, C., and Ehrenstein, M. R. (2007). Anti-TNF-alpha therapy induces a distinct regulatory $\mathrm{T}$ cell population in patients with rheumatoid arthritis via TGFbeta. J. Exp. Med. 204, 33-39. doi:10.1084/jem.20061531

Nagar, M., Jacob-Hirsch, J., Vernitsky, H., Berkun, Y., Ben-Horin, S., Amariglio, N., et al. (2010). TNF activates a NF-kappaB-regulated cellular program in human CD45RAregulatory $\mathrm{T}$ cells that modulates their suppressive function. J. Immunol. 184, 3570-3581. doi:10.4049/jimmunol.0902070

Nie, H., Zheng, Y., Li, R., Guo, T. B., He, D., Fang, L., et al. (2013). Phosphorylation of FOXP3 controls regulatory $\mathrm{T}$ cell function and is inhibited by TNF-alpha in rheumatoid arthritis. Nat. Med. 19, 322-328. doi:10.1038/nm.3085

Nishikawa, H., Kato, T., Tanida, K., Hiasa, A., Tawara, I., Ikeda, H., et al. (2003). CD4+CD25+ T cells responding to serologically defined autoantigens suppress antitumor immune responses. Proc. Natl. Acad. Sci. U.S.A. 100, 10902-10906. doi:10.1073/pnas.1834479100

Nykjaer, A., Moller, B., Todd, R. F. III, Christensen, T., Andreasen, P. A., 
Gliemann, J., et al. (1994). Urokinase receptor. An activation antigen in human T lymphocytes. J. Immunol. $152,505-516$.

Ochando, J. C., Homma, C., Yang, Y., Hidalgo, A., Garin, A., Tacke, F., et al. (2006). Alloantigenpresenting plasmacytoid dendritic cells mediate tolerance to vascularized grafts. Nat. Immunol. 7, 652-662. doi:10.1038/ni1333

Odekon, L. E., Blasi, F., and Rifkin, D. B. (1994). Requirement for receptor-bound urokinase in plasmin-dependent cellular conversion of latent TGF-beta to TGF-beta. J. Cell. Physiol. 158, 398-407. doi:10.1002/jcp. 1041580303

Ohkura, N., Hamaguchi, M., Morikawa, H., Sugimura, K., Tanaka, A., Ito, Y., et al. (2012). T cell receptor stimulation-induced epigenetic changes and Foxp3 expression are independent and complementary events required for Treg cell development. Immunity 37, 785-799. doi:10.1016/j.immuni.2012.09.010

Ohkura, N., Kitagawa, Y., and Sakaguchi, S. (2013). Development and maintenance of regulatory $\mathrm{T}$ cells. Immunity 38, 414-423. doi:10.1016/j.immuni.2013.03.002

Oldenhove, G., Bouladoux, N., Wohlfert, E. A., Hall, J. A., Chou, D., Dos Santos, L., et al. (2009). Decrease of Foxp3+ Treg cell number and acquisition of effector cell phenotype during lethal infection. Immunity 31, 772-786. doi:10.1016/j.immuni.2009.10.001

Passerini, L., Allan, S. E., Battaglia, M., Di Nunzio, S., Alstad, A. N., Levings, M. K., et al. (2008). STAT5-signaling cytokines regulate the expression of FOXP3 in CD4+CD25+ regulatory $\mathrm{T}$ cells and $\mathrm{CD} 4+\mathrm{CD} 25-$ effector $\mathrm{T}$ cells. Int. Immunol. 20, 421-431. doi:10.1093/intimm/dxn002

Perez-Alvarez, R., Perez-de-Lis, M., Ramos-Casals, M., and BIOGEAS study group (2013). Biologicsinduced autoimmune diseases. Curr. Opin. Rheumatol. 25, 56-64. doi:10.1097/BOR.0b013e32835b 1366

Polansky, J. K., Kretschmer, K., Freyer, J., Floess, S., Garbe, A., Baron, U., et al. (2008). DNA methylation controls Foxp3 gene expression. Eur. J. Immunol. 38, 1654-1663. doi:10.1002/eji.200838105

Prud'Homme, G. J. (2007). Pathobiology of transforming growth factor beta in cancer, fibrosis and immunologic disease, and therapeutic considerations. Lab. Invest. 87, 1077-1091. doi:10.1038/labinvest.3700669
Rauert, H., Wicovsky, A., Muller, N., Siegmund, D., Spindler, V., Waschke, J., et al. (2010). Membrane tumor necrosis factor (TNF) induces p100 processing via TNF receptor-2 (TNFR2). J. Biol. Chem. 285, 7394-7404 doi:10.1074/jbc.M109.037341

Robertson, S. J., Messer, R. J., Carmody, A. B., and Hasenkrug, K. J. (2006). In vitro suppression of CD8+ T cell function by Friend virus-induced regulatory T cells. J. Immunol. 176, 3342-3349.

Rubtsov, Y. P., Niec, R. E., Josefowicz, S., Li, L., Darce, J., Mathis, D., et al. (2010). Stability of the regulatory $\mathrm{T}$ cell lineage in vivo. Science 329, 1667-1671. doi:10.1126/science.1191996

Ruddle, N. H., Bergman, C. M., McGrath, K. M., Lingenheld, E. G., Grunnet, M. L., Padula, S. J., et al. (1990). An antibody to lymphotoxin and tumor necrosis factor prevents transfer of experimental allergic encephalomyelitis. J. Exp. Med. 172, 1193-1200. doi:10.1084/jem.172.4.1193

Saadoun, D., Rosenzwajg, M., Joly, F., Six, A., Carrat, F., Thibault, V., et al. (2011). Regulatory T-cell responses to low-dose interleukin2 in HCV-induced vasculitis. $N$. Engl. J. Med. 365, 2067-2077. doi:10.1056/NEJMoa1105143

Sadlack, B., Lohler, J., Schorle, H., Klebb, G., Haber, H., Sickel, E., et al. (1995). Generalized autoimmune disease in interleukin-2-deficient mice is triggered by an uncontrolled activation and proliferation of $\mathrm{CD} 4+\mathrm{T}$ cells. Eur. J. Immunol. 25, 3053-3059. doi:10.1002/eji.1830251111

Sadlack, B., Merz, H., Schorle, H., Schimpl, A., Feller, A. C., and Horak, I. (1993). Ulcerative colitis-like disease in mice with a disrupted interleukin-2 gene. Cell 75, 253-261. doi:10.1016/0092-8674(93)80067-O

Sakaguchi, S., Sakaguchi, N., Asano, M., Itoh, M., and Toda, M. (1995). Immunologic self-tolerance maintained by activated $\mathrm{T}$ cells expressing IL-2 receptor alpha-chains (CD25). Breakdown of a single mechanism of self-tolerance causes various autoimmune diseases. J. Immunol. 155, 1151-1164.

Sauer, S., Bruno, L., Hertweck, A., Finlay, D., Leleu, M., Spivakov, M., et al. (2008). T cell receptor signaling controls Foxp3 expression via PI3K, Akt, and mTOR. Proc. Natl. Acad. Sci. U.S.A. 105, 7797-7802. doi:10.1073/pnas.0800928105

Setoguchi, R., Hori, S., Takahashi, T., and Sakaguchi, S. (2005).
Homeostatic maintenance of natural Foxp3(+) CD25(+) CD4(+) regulatory $\mathrm{T}$ cells by interleukin (IL)-2 and induction of autoimmune disease by IL-2 neutralization. J. Exp. Med. 201, 723-735. doi:10.1084/jem.20041982

Sgouroudis, E., Albanese, A., and Piccirillo, C. A. (2008). Impact of protective IL-2 allelic variants on CD4+ Foxp3+ regulatory $\mathrm{T}$ cell function in situ and resistance to autoimmune diabetes in NOD mice. J. Immunol. 181, 6283-6292.

Sgouroudis, E., Kornete, M., and Piccirillo, C. A. (2011). IL-2 production by dendritic cells promotes Foxp3(+) regulatory T-cell expansion in autoimmuneresistant NOD congenic mice. Autoimmunity $\quad 44, \quad 406-414$ doi:10.3109/08916934.2010.536795

Shin, H. J., Baker, J., Leveson-Gower, D. B., Smith, A. T., Sega, E. I., and Negrin, R. S. (2011). Rapamycin and IL-2 reduce lethal acute graftversus-host disease associated with increased expansion of donor type CD4+CD25+Foxp3+ regulatory $\mathrm{T}$ cells. Blood 118, 2342-2350. doi:10.1182/blood-2010-10-313684

Shull, M. M., Ormsby, I., Kier, A. B., Pawlowski, S., Diebold, R. J., Yin, M., et al. (1992). Targeted disruption of the mouse transforming growth factor-beta 1 gene results in multifocal inflammatory disease. Nature 359, 693-699. doi:10.1038/359693a0

Smith, K. A., Baker, P. E., Gillis, S., and Ruscetti, F. W. (1980). Functional and molecular characteristics of T-cell growth factor. Mol. Immunol. 17, 579-589. doi:10.1016/0161-5890(80)90156-X

Soper, D. M., Kasprowicz, D. J., and Ziegler, S. F. (2007). IL-2Rbeta links IL-2R signaling with Foxp3 expression. Eur. J. Immunol. 37, 1817-1826. doi:10.1002/eji.200737101

Strainic, M. G., Shevach, E. M., An, F., Lin, F., and Medof, M. E. (2013). Absence of signaling into CD4(+) cells via $\mathrm{C} 3 \mathrm{aR}$ and $\mathrm{C} 5 \mathrm{aR}$ enables autoinductive TGF-betal signaling and induction of Foxp3(+) regulatory T cells. Nat. Immunol. 14, 162-171. doi:10.1038/ni.2499

Sugimoto, N., Oida, T., Hirota, K., Nakamura, K., Nomura, T., Uchiyama, T., et al. (2006). Foxp3-dependent and -independent molecules specific for $\mathrm{CD} 25+\mathrm{CD} 4+$ natural regulatory $\mathrm{T}$ cells revealed by DNA microarray analysis. Int. Immunol. 18, 1197-1209. doi:10.1093/intimm/dxl060

Sun, C. M., Hall, J. A., Blank, R. B., Bouladoux, N., Oukka, M.,
Mora, J. R., et al. (2007). Small intestine lamina propria dendritic cells promote de novo generation of Foxp3 $\mathrm{T}$ reg cells via retinoic acid. J. Exp. Med. 204, 1775-1785. doi:10.1084/jem.20070602

Sun, S. C. (2011). Non-canonical NFkappaB signaling pathway. Cell Res. 21, 71-85. doi:10.1038/cr.2010.177

Suzuki, H., Kundig, T. M., Furlonger, C., Wakeham, A., Timms, E., Matsuyama, T., et al. (1995). Deregulated $\mathrm{T}$ cell activation and autoimmunity in mice lacking interleukin-2 receptor beta. Science 268, 1472-1476. doi:10.1126/science.7770771

Tang, Q., Adams, J. Y., Penaranda, C., Melli, K., Piaggio, E., Sgouroudis, E., et al. (2008). Central role of defective interleukin-2 production in the triggering of islet autoimmune destruction. Immunity 28, 687-697. doi:10.1016/j.immuni.2008.03.016

Todd, J. A., Walker, N. M., Cooper, J. D., Smyth, D. J., Downes, K., Plagnol, V., et al. (2007). Robust associations of four new chromosome regions from genome-wide analyses of type 1 diabetes. Nat. Genet. 39, 857-864. doi:10.1038/ng2068

Toker, A., Engelbert, D., Garg, G. Polansky, J. K., Floess, S., Miyao, T., et al. (2013). Active demethylation of the Foxp3 locus leads to the generation of stable regulatory $\mathrm{T}$ cells within the thymus. J. Immunol. 190, 3180-3188. doi:10.4049/jimmunol.1203473

Tone, Y., Furuuchi, K., Kojima, Y., Tykocinski, M. L., Greene, M. I., and Tone, M. (2008). Smad3 and NFAT cooperate to induce Foxp3 expression through its enhancer. Nat. Immunol. 9, 194-202. doi:10.1038/ni1549

Valencia, X., Stephens, G., GoldbachMansky, R., Wilson, M., Shevach, E. M., and Lipsky, P. E. (2006) TNF downmodulates the function of human CD4+CD25hi Tregulatory cells. Blood 108, 253-261. doi:10.1182/blood-2005-11-4567

van Mierlo, G. J., Scherer, H. U., Hameetman, M., Morgan, M. E., Flierman, R., Huizinga, T. W., et al. (2008). Cutting edge: TNFRshedding by $\mathrm{CD} 4+\mathrm{CD} 25+$ regulatory $\mathrm{T}$ cells inhibits the induction of inflammatory mediators. $J$. Immunol. 180, 2747-2751.

Vella, A., Cooper, J. D., Lowe, C. E., Walker, N., Nutland, S., Widmer, B., et al. (2005). Localization of a type 1 diabetes locus in the IL2RA/CD25 region by use of tag single-nucleotide polymorphisms. Am. J. Hum. Genet. 76, 773-779. doi:10.1086/429843 
Vignali, D. A., Collison, L. W., and Workman, C. J. (2008). How regulatory T cells work. Nat. Rev. Immunol. 8 , 523-532. doi:10.1038/nri2343

Walker, M. R., Kasprowicz, D. J., Gersuk, V. H., Benard, A., Van Landeghen, M., Buckner, J. H., et al. (2003). Induction of FoxP3 and acquisition of $\mathrm{T}$ regulatory activity by stimulated human CD4+CD25- T cells. J. Clin. Invest. 112, 1437-1443. doi:10.1172/JCI200319441

Wang, Y., Su, M. A., and Wan, Y. Y. (2011). An essential role of the transcription factor GATA3 for the function of regulatory $\mathrm{T}$ cells. Immunity 35, 337-348. doi:10.1016/j.immuni.2011.08.012

Webster, K. E., Walters, S., Kohler, R. E., Mrkvan, T., Boyman, O., Surh, C. D., et al. (2009). In vivo expansion of $\mathrm{T}$ reg cells with IL-2-mAb complexes: induction of resistance to EAE and long-term acceptance of islet allografts without immunosuppression. J. Exp. Med. 206, 751-760. doi:10.1084/jem.20082824

Willenborg, D. O., Fordham, S. A., Cowden, W. B., and Ramshaw, I. A. (1995). Cytokines and murine autoimmune encephalomyelitis: inhibition or enhancement of disease with antibodies to select cytokines, or by delivery of exogenous cytokines using a recombinant vaccinia virus system. Scand. J. Immunol. 41, 31-41. doi:10.1111/j.13653083.1995.tb03530.x

Willerford, D. M., Chen, J., Ferry, J. A., Davidson, L., Ma, A., and Alt, F. W. (1995). Interleukin-2 receptor alpha chain regulates the size and content of the peripheral lymphoid compartment. Immunity 3, 521-530. doi:10.1016/10747613(95)90180-9

Wilson, M. S., Pesce, J. T., Ramalingam, T. R., Thompson, R. W., Cheever, A., and Wynn, T. A. (2008). Suppression of murine allergic airway disease by IL-2:antiIL-2 monoclonal antibody-induced regulatory T cells. J. Immunol. 181, 6942-6954.

Wohlfert, E. A., Grainger, J. R., Bouladoux, N., Konkel, J. E., Oldenhove, G., Ribeiro, C. H., et al. (2011). GATA3 controls Foxp3(+) regulatory $\mathrm{T}$ cell fate during inflammation in mice. J. Clin. Invest. 121, 4503-4515. doi:10.1172/JCI57456

$\mathrm{Wu}$, A. J., Hua, H., Munson, S. H., and McDevitt, H. O. (2002). Tumor necrosis factor-alpha regulation of $\mathrm{CD} 4+\mathrm{CD} 25+\mathrm{T}$ cell levels in NOD mice. Proc. Natl. Acad. Sci. U.S.A. 99, 12287-12292. doi:10.1073/pnas.172382999

Wu, Y., Borde, M., Heissmeyer, V., Feuerer, M., Lapan, A. D., Stroud, J. C., et al. (2006). FOXP3 controls regulatory $\mathrm{T}$ cell function through cooperation with NFAT. Cell 126, 375-387. doi:10.1016/j.cell.2006.05.042

Xu, L., Kitani, A., and Strober, W. (2010). Molecular mechanisms regulating TGF-beta-induced Foxp3 expression. Mucosal Immunol. 3, 230-238. doi:10.1038/mi.2010.7

Yamanouchi, J., Rainbow, D., Serra, P., Howlett, S., Hunter, K., Garner, V. E., et al. (2007). Interleukin-2 gene variation impairs regulatory $\mathrm{T}$ cell function and causes autoimmunity. Nat. Genet. 39, 329-337. doi:10.1038/ng1958

Yamazaki, S., Bonito, A. J., Spisek, R., Dhodapkar, M., Inaba, K., and Steinman, R. M. (2007). Dendritic cells are specialized accessory cells along with TGF- for the differentiation of Foxp3+ CD4+ regulatory $\mathrm{T}$ cells from peripheral Foxp3 precursors. Blood 110, 4293-4302. doi:10.1182/blood2007-05-088831

Yamazaki, S., Dudziak, D., Heidkamp, G. F., Fiorese, C., Bonito, A. J., Inaba, K., et al. (2008). CD8+ CD205+ splenic dendritic cells are specialized to induce Foxp3+ regulatory T cells. J. Immunol. 181, 6923-6933.

Yang, X. D., Tisch, R., Singer, S. M. Cao, Z. A., Liblau, R. S., Schreiber R. D., et al. (1994). Effect of tumor necrosis factor alpha on insulindependent diabetes mellitus in NOD mice. I. The early development of autoimmunity and the diabetogenic process. J. Exp. Med. 180, 995-1004. doi:10.1084/jem.180.3.995

Yao, Z., Kanno, Y., Kerenyi, M. Stephens, G., Durant, L., Watford, W. T., et al. (2007). Nonredundant roles for $S t a t 5 \mathrm{a} / \mathrm{b}$ in directly regulating Foxp3. Blood 109, 4368-4375. doi:10.1182/blood2006-11-055756

Zanin-Zhorov, A., Ding, Y., Kumari, S. Attur, M., Hippen, K. L., Brown, M., et al. (2010). Protein kinase Ctheta mediates negative feedback on regulatory $\mathrm{T}$ cell function. Science 328, 372-376. doi:10.1126/science. 1186068

Zhang, N., and Bevan, M. J. (2012). TGF-beta signaling to $\mathrm{T}$ cells inhibits autoimmunity during lymphopenia-driven proliferation. Nat. Immunol. 13, 667-673. doi:10.1038/ni.2319

Zhang, Q., Cui, F., Fang, L., Hong, J., Zheng, B., and Zhang, J. Z. (2013). TNF-alpha impairs differentiation and function of TGF-beta-induced Treg cells in autoimmune diseases through Akt and Smad3 signaling pathway. J. Mol. Cell Biol. 5, 85-98. doi:10.1093/jmcb/mjs063

Zheng, S. G., Wang, J., Wang, P., Gray, J. D., and Horwitz, D. A. (2007) IL-2 is essential for TGF-beta to convert naive CD4+CD25- cells to CD25+Foxp3+ regulatory $\mathrm{T}$ cells and for expansion of these cells. $J$. Immunol. 178, 2018-2027.

Zheng, Y., Josefowicz, S., Chaudhry, A., Peng, X. P., Forbush, K., and Rudensky, A. Y. (2010). Role of conserved non-coding DNA elements in the Foxp3 gene in regulatory
T-cell fate. Nature 463, 808-812. doi: $10.1038 /$ nature 08750

Zhou, X., Bailey-Bucktrout, S. L., Jeker, L. T., Penaranda, C., MartinezLlordella, M., Ashby, M., et al. (2009). Instability of the transcription factor Foxp3 leads to the generation of pathogenic memory $\mathrm{T}$ cells in vivo. Nat. Immunol. 10, 1000-1007. doi:10.1038/ni. 1774

Zorn, E., Nelson, E. A., Mohseni, M., Porcheray, F., Kim, H., Litsa, D., et al. (2006). IL-2 regulates FOXP3 expression in human $\mathrm{CD} 4+\mathrm{CD} 25+$ regulatory $\mathrm{T}$ cells through a STAT-dependent mechanism and induces the expansion of these cells in vivo. Blood 108, 1571-1579. doi:10.1182/blood2006-02-004747

Conflict of Interest Statement: The authors declare that the research was conducted in the absence of any commercial or financial relationships that could be construed as a potential conflict of interest.

Received: 30 April 2013; accepted: 06 June 2013; published online: 19 June 2013.

Citation: Goldstein JD, Pérol L, Zaragoza

B, Baeyens A, Marodon $G$ and Piaggio $E$ (2013) Role of cytokines in thymus- versus peripherally derivedregulatory $T$ cell differentiation and function. Front. Immunol. 4:155. doi: 10.3389/fimmu.2013.00155

This article was submitted to Frontiers in Immunological Tolerance, a specialty of Frontiers in Immunology.

Copyright (C) 2013 Goldstein, Pérol, Zaragoza, Baeyens, Marodon and Piaggio. This is an open-access article distributed under the terms of the Creative Commons Attribution License, which permits use, distribution and reproduction in other forums, provided the original authors and source are credited and subject to any copyright notices concerning any third-party graphics etc. 